\title{
The Economic Lives of the Poor
}

\author{
Abhijit V. Banerjee [Professor of Economics; Director of the Abdul Latif Jameel Poverty \\ Action Lab] and Esther Duflo [Professor of Economics; Director of the Abdul Latif Jameel \\ Poverty Action Lab] \\ Massachusetts Institute of Technology, Cambridge, Massachusetts.
}

In what turned out to be a rhetorical master-move, the 1990 World Development Report from the World Bank defined the "extremely poor" people of the world as those who are currently living on no more than $\$ 1$ per day per person, measured at the 1985 purchasing power parity (PPP) exchange rate. In 1993, the poverty line was updated to $\$ 1.08$ per person per day at the 1993 PPP exchange rate, which is the line we use in this paper. Poverty lines have always existed-indeed $\$ 1$ per day was chosen in part because of its proximity to the poverty lines used by many poor countries. ${ }^{1}$ However the $\$ 1$-a-day poverty line has come to dominate the conversations about poverty to a remarkable extent.

But how actually does one live on less than $\$ 1$ per day? This essay is about the economic lives of the extremely poor: the choices they face, the constraints they grapple with, and the challenges they meet. The available evidence on the economic lives of the extremely poor is incomplete in many important ways. However, a number of recent data sets and a body of new research have added a lot to what we know about their lives, and taken together there is enough to start building an image of the way the extremely poor live their lives.

Our discussion of the economic lives of the extremely poor builds on household surveys conducted in 13 countries listed in Table 1: Cote d'Ivoire, Guatemala, India, Indonesia, Mexico, Nicaragua, Pakistan, Panama, Papua New Guinea, Peru, South Africa, Tanzania, and Timor Leste (East Timor). We mainly use the Living Standard Measurement Surveys (LSMS) conducted by the World Bank and the "Family Life Surveys" conducted by the Rand Corporation, all of which are publicly available. In addition, we also use two surveys that we conducted in India with our collaborators. The first was carried out in 2002 and 2003 in 100 hamlets of Udaipur District, Rajasthan (Banerjee, Deaton, and Duflo, 2004). Udaipur is one of the poorer districts of India, with a large tribal population and an unusually high level of female illiteracy. (At the time of the 1991 census, only 5 percent of women were literate in rural Udaipur.) Our second survey covered 2,000 households in "slums" (or informal neighborhoods) of Hyderabad, the capital of the state of Andhra Pradesh and one of the boomtowns of post-liberalization India (Banerjee, Duflo, and Glennerster, 2006). We chose these countries and surveys because they provide detailed information on extremely poor households around the world, from Asia to Africa to Latin America, including information on what they consume, where they work, and how they save and borrow. To flesh out our main themes further, we also draw freely on the existing research literature.

From each of these surveys we identified the extremely poor as those living in households where the consumption per capita is less than $\$ 1.08$ per person per day, as well as the merely "poor" defined as those who live under $\$ 2.16$ a day using 1993 purchasing power parity (PPP) as benchmark. In keeping with convention, we call these the $\$ 1$ and $\$ 2$ dollar poverty lines,

\footnotetext{
${ }^{1}$ For example, the "All India Rural” poverty line used by the Indian Planning Commission was 328 rupees per person per month, or $\$ 32$ in purchasing power parity (PPP) dollars in 1999/2000.
} 
respectively. The use of consumption, rather than income, is motivated by the better quality of the consumption data in these surveys (Deaton, 2004). Table 1 provides some background information on these surveys. It lists the countries, and the source of the survey data. It also lists the sample sizes: the numbers and the proportions of the extremely poor and the poor in each survey. The fraction of individuals living under $\$ 1$ dollar per day in the survey vary from 2 percent in Panama to 47 percent in Udaipur, and the fraction living under $\$ 2$ per day varies from 6 percent in Panama to 86 percent in Udaipur. All the numbers discussed in this paper and detailed results are available in an appendix that appears with the on-line version of this article at 〈http://www.e-jep.org $\rangle$.

The way in which we identify the poor does raise questions. Purchasing power parity exchange rates, which are essential to compute a "uniform" poverty line, have been criticized as inadequate, infrequently updated, and inapplicable to the consumption of the extremely poor (Deaton, 2004, 2006). Prices are typically higher in urban than in rural areas, and even in rural areas, the poor may pay different prices than everyone else. Also, reporting periods vary significantly from survey to survey and this has been shown to affect systematically what people report.

But while these issues are obviously serious for counting the exact number of the poor, they may affect the conclusions of this essay less because instead of counting the poor, we are describing what their lives look like. Misclassifying some households should not change anything very important about the averages we observe in the data, unless both the number affected are very large and those artificially moved into or out of poverty by changes in the poverty line are very different than the other poor. It turns out that most of our conclusions do not change if we look at the poor rather than the extremely poor, which is reassuring.

Nevertheless, we cannot entirely rule out the possibility that our results may be different with a different poverty line.

We also assume that the people we are describing as the poor are long-term poor, in the sense that their permanent income is actually close to their observed consumption. If the poor people we observe are just making a brief transition through poverty, then some of the behaviors that we will observe (such as lack of savings) would be less puzzling, and others (like the lack of assets) would be much more so. We feel that this assumption is a reasonable one in most of the countries, since the fraction of the population below $\$ 2.16$ a day is actually sizeable -40 percent of the population or more in the median country and more than 70 percent in quite a few. Thus, it is unlikely that many of these people are just temporarily poor. However, for this reason, the poor in Panama, where only 6 percent of the population is poor, or in South Africa, where 19 percent is poor, may not be easily compared to the poor in some of the other countries, where the poor are a much larger share of the population.

\section{The Living Arrangements of the Poor}

The typical extremely poor family tends to be large, at least by the standards of today's highincome countries. The number of family members varies between about six and twelve, with a median value (across the different countries) of between seven and eight, compared to 2.5 in the 2000 U.S. census, for example.

Not all surveys report fertility rates, which would be the ideal way to distinguish whether these high numbers result from the average woman having a lot of children, or if it results from an extended family living together. However, the data does give broad measures of the age structure in these families (the number of those below 13, between 13 and 18, above 51, and so on). The number of adults (over age 18) ranges from about 2.5 to about five, with a median of about three, which suggests a family structure where it is common for adults to live with 
parents, siblings, uncles, cousins, and so on. This finding is common in the literature on developing countries. When every penny counts, it helps to spread the fixed costs of living, like housing, over a larger number of people. Consistent with this view, family size is larger for the extremely poor than for the entire group below $\$ 2$ a day, on the order of one half of one person or more, though at least some part of this difference is because extremely poor families have more children living with them.

These families also have a large number of children. This fact does not necessarily imply high levels of fertility, as families often have multiple adult women. When we look at the number of children (ages 0 to 18) per woman in the child-bearing age (ages 21-50) we get numbers between two and four in both the rural and the urban sample, though the urban ratios tend to be slightly lower. This ratio cannot be interpreted as a fertility rate, because for example, a 51 year-old could have a child who is now 36 , but we only include children who are below age 18. A more useful exercise with this data is to compare the number of young people (those below 18) in these families with the number of older people (those above 51). The ratio varies between three and nine in the rural sample, with a median of six, and between two and eleven in the urban sample, again with a median around six. The corresponding ratio in the United States is around one. The poor of the world are very young.

One reason the population is young is that there are a lot of younger people. A complementary reason is that there are very few older people. The ratio of the number older people (over age $51)$ to the number of people of "prime-age" (21-50) tends to be between 0.2 and 0.3 in both the rural and the urban sample. The corresponding number in the United States is approximately 0.6. A plausible explanation for this difference might be the higher mortality rates among those who are older and poor in poor countries, but in principle it is possible that it is an artifact of the way we constructed our sample. It could be that older people are underrepresented in our sample because they tend to be richer. But in this case, we might have expected to find more of the older people among the poor (as compared to the extremely poor), whereas the data does not show such a pattern.

\section{How the Poor Spend Their Money}

A common image of the extremely poor is that they have few real choices to make. Indeed, some people surely work as hard as they can —which may not be particularly hard, because they are underfed and weak and earn barely enough to cover their basic needs, which they always try to fulfill in the least expensive way. Historically, poverty lines in many countries were originally set to capture this definition of poverty - the budget needed to buy a certain amount of calories, plus some other indispensable purchases (such as housing). A "poor" person was essentially defined as someone without enough to eat.

\section{Food and Other Consumption Purchases}

Yet the average person living at under $\$ 1$ per day does not seem to put every available penny into buying more calories. Among our 13 countries, food typically represents from 56 to 78 percent of consumption among rural households, and 56 to 74 percent in urban areas. For the rural poor in Mexico, slightly less than half the budget (49.6 percent) is allocated to food. ${ }^{2}$

Of course, these people could be spending the rest of their money on other commodities they greatly need. Yet among the nonfood items that the poor spend significant amounts of money on, alcohol and tobacco show up prominently. The extremely poor in rural areas spent 4.1 percent of their budget on tobacco and alcohol in Papua New Guinea; 5.0 percent in Udaipur, India; 6.0 percent in Indonesia; and 8.1 percent in Mexico. However, in Guatemala, Nicaragua, and Peru, no more than 1 percent of the budget gets spent on these goods (possibly because the poor in these countries prefer other intoxicants). 
Perhaps more surprisingly, spending on festivals is an important part of the budget for many extremely poor households. In Udaipur, over the course of the previous year, more than 99 percent of the extremely poor households spent money on a wedding, a funeral, or a religious festival. The median household spent 10 percent of its annual budget on festivals. In South Africa, 90 percent of the households living under $\$ 1$ per day spent money on festivals. In Pakistan, Indonesia, and Cote d'Ivoire, more than 50 percent did likewise. Only in some Latin American countries in our sample—Panama, Guatemala, Nicaragua - are festivals not a notable part of the yearly expenditure for a significant fraction of the households. However, in the LSMS surveys, unlike the Udaipur survey, people are not asked to account separately for the food that they bought because of a festival. It is therefore probably no accident that the Udaipur spending on festivals is the highest across the surveys. The LSMS numbers would probably have been higher if data on food spending because of festivals had been directly collected in those surveys.

On the other hand, the under-\$1-per-day households spend very little on forms of entertainment common in high-income countries such as movies, theater, or video shows. In all 13 countries in our sample, in the month preceding the survey the average extremely poor household spent less than 1 percent on any of these forms of entertainment. The comparable number for the United States is 5 percent. We can only speculate about the roots of this difference. Has the importance given to festivals and other indigenous forms of entertainment crowded out moviegoing? Or is the answer as simple as a lack of access to movie theaters?

The propensity to own a radio or a television, a widespread form of entertainment for American households, varies considerably across low-income countries. For example, among rural households living under $\$ 1$ per day, ownership of a radio is 11 percent in the Udaipur survey, almost 60 percent in Nicaragua and Guatemala, and above 70 percent in South Africa and Peru. Similarly, no one owns a television in Udaipur, but in Guatemala nearly a quarter of households do, and in Nicaragua, the percentage is closer to a half.

These phenomena of spending on festivals and ownership of radios or televisions appear to be related. In Udaipur, where the share spent on festivals is the highest, radio and television ownership is very low. In Pakistan, the fraction spent on festivals is 3.3 percent and only 30 percent have a radio. By contrast, in Nicaragua where among respectively the rural and the urban poor 57 and 38 percent have a radio and 21 percent and 19 percent own a television, very few households report spending anything on festivals. ${ }^{3}$ One wrinkle on this explanation is that the urban poor who are much more likely to own a television than the rural poor (60 versus 33 percent in Indonesia, 61 versus 10 percent in Peru, 38 versus 17 percent in South Africa), do not spend less on festivals than their rural counterparts. While this observation is based on only a few data points, it hints at the possibility of an unmet demand for entertainment

\footnotetext{
${ }^{2}$ The fact that the share spent on food, which is often seen as a physiological necessity, varies so much across countries is itself interesting. One possibility is that this represents the fact that the poor have more choice in some countries than in others, because consumption goods are cheap relative to food in some countries. For example, India, a large economy with a long history of being relatively closed, has evolved a large menu of low-cost and lower-quality consumer goods that are produced almost exclusively for the domestic market, examples include tooth-paste, cigarettes, and clothing. Other countries must buy these goods at higher prices on the global market. If the manufactured consumer goods that the average person buys in India tend to be inexpensive relative to their traded counterparts, the ratio between the consumption exchange rate at purchasing power parity and the official exchange rate ought to be relatively low in India. More generally: the lower this ratio, the lower is the share of the consumption that should be made up of food. In our data, it turns out that the correlation between the ratio of the PPP exchange rate for consumption to the official exchange rate in 1993 and the share of expenditure spent on food is 0.33 among these 12 countries, although this sample is of course too small to support a definite conclusion. ${ }^{3}$ The ultimate source of variation here might be the relative prices of radios and televisions. There is a strong correlation between the ratio of the purchasing power exchange rate for consumption to the official exchange rate, and the probability that a household owns a radio (the correlation is 0.36 ). The logic is probably quite similar to the argument presented earlier in the context of food consumption in footnote 2. Radios are tradable (they are essentially all made in China). Nontradable goods are much less costly in some countries than others, while traded goods tend to be more similarly priced, so people at the same expenditure levels at purchasing power parity can have widely differing levels of purchasing power in terms of traded goods.
} 
among the rural poor - they might like to buy a television, but perhaps the television signal does not reach their neighborhoods.

In either case, the poor do see themselves as having a significant amount of choice, but they choose not to exercise that choice in the direction of spending more on food. The typical poor household in Udaipur could spend up to 30 percent more on food than it actually does, just based on what it spends on alcohol, tobacco, and festivals. Indeed, in most of the surveys the share spent on food is about the same for the poor and the extremely poor, suggesting that the extremely poor feel no extra compulsion to purchase more calories.

This conclusion echoes an old finding in the literature on nutrition: even the extremely poor do not seem to be as hungry for additional calories as one might expect. Deaton and Subramanian (1996), using 1983 data from the Indian state of Maharashtra, found that even for the poorest, a 1 percent increase on overall expenditure translates into about a two-thirds of a percent increase in the total food expenditure of a poor family. Remarkably, the elasticity is not very different for the poorest individuals in the sample and the richest (although nobody is particularly rich in this sample). The Deaton and Subramanian estimate is one of the higher estimates. Thomas and Strauss (1997) found an elasticity of demand for food with respect to expenditure per capita of about a quarter for the poorest Brazilians.

Another way to make the same point is to look at what edibles the extremely poor are buying. Deaton and Subramanian (1996) note that among grains, in terms of calories per rupee, the millets (jowar and bajra) are clearly the best buy. Yet in their data, only about two-thirds of the total spending on grains is on these grains, while another 20 percent is on rice, which costs more than twice as much per calorie, and a further 10 percent or so is spent on wheat, which is a 70 percent more expensive way to get calories. In addition, the poor spend almost 7 percent of their total budget on sugar, which is both more expensive than grains as a source of calories and bereft of other nutritional value. The same affinity for sugar also shows up in our Udaipur data, in which the poor spend almost 10 percent of their food budget on the category "sugar, salt, and other processed foods" (this does not include cooking oil, which makes up another 6 percent of the expenditures on food). Even for the extremely poor, for every 1 percent increase in the food expenditure, about half goes into purchasing more calories, and half goes into purchasing more expensive (and presumably better tasting) calories.

Finally, the trend seems to be to spend even less money on food. In India, for example, spending on food went from 70 percent in 1983 to 62 percent in 1999-2000, and the share of millet in the food budget dropped to virtually zero (Deaton, 2006). Not surprisingly, the poor are also consuming fewer calories over time (Meenakshi and Vishwanathan, 2003), though this change may also reflect that their work involves less physical effort (Jha, 2004).

\section{The Ownership of Assets}

While all the surveys have some information about assets, the list of assets varies. To obtain a relatively coherent list across countries, we focus on radios, televisions, and bicycles. The share of people who own these particular assets varies significantly across countries.

As we already discussed, ownership of radio and television varies from country to country, but is low in some countries. One reason may be the lack of signal. Another reason may be that a television is an expensive and lumpy transaction for which one has to save if one is born poor. We do see a fairly steep income gradient in the ownership of radio and television: In all countries, the share of rural households owning a television is substantially larger for those who live on less than $\$ 2$ a day than those living on less than $\$ 1$ a day. For example, the share owning a television increases from 14 percent for those living on $\$ 1$ a day to 45 percent for those living on less than $\$ 2$ a dollar a day in Cote d'Ivoire; from 7 to 17 percent in South Africa; 
and from 10 to 21 percent in Peru. This pattern has been observed in other contexts (Filmer and Pritchett, 2001) and has been the basis for using the lack of durable goods as a marker for poverty. Our data suggests that this proxy can be appropriate within a country, but it could easily be misleading in a cross-country comparison.

Among productive assets, land is the one that many people in the rural surveys seem to own, although enormous country-to-country variation exists. Only 4 percent of those living under $\$ 1$ a day own land in Mexico, 1.4 percent in South Africa, 30 percent in Pakistan, 37 percent in Guatemala, 50 percent in Nicaragua and Indonesia, 63 percent in Cote d'Ivoire, 65 percent in Peru, and 85 percent in Panama. In the Udaipur sample, 99 percent of the households below $\$ 1$ a day own some land in addition to the land on which their house is built, although much of it is dry scrubland that cannot be cultivated for most of the year. However, when the extremely poor do own land, the plots tend to be quite small. The median landholding among the poor who own land is one hectare or less in Udaipur, Indonesia, Guatemala, and Timor; between one and two hectares in Peru, Tanzania, Pakistan; and between two and three hectares in Nicaragua, Cote d'Ivoire, and Panama.

Apart from land, extremely poor households in rural areas tend to own very few durable goods, including productive assets: 34 percent own a bicycle in Cote d'Ivoire, but less than 14 percent in Udaipur, Nicaragua, Panama, Papua New Guinea, Peru, and East Timor. In Udaipur, where we have detailed asset data, most extremely poor households have a bed or a cot, but only about 10 percent have a chair or a stool and 5 percent have a table. About half have a clock or a watch. Fewer than 1 percent have an electric fan, a sewing machine, a bullock cart, a motorized cycle of any kind, or a tractor. No one has a phone. As we will see below, this situation does not mean that most of these households are employees and have little use for such assets. On the contrary, many extremely poor households operate their own businesses, but do so with almost no productive assets.

\section{The Pursuit of Health and Well-being}

Should we worry about the fact that the poor are buying less food than they could? According to Deaton and Subramanian (1996), the poorest people- the ones in the bottom decile in terms of per capita expenditure - consume on average slightly less than 1400 calories a day. This level is about half of what the Indian government recommends for a man with moderate activity, or a woman with heavy physical activity (see

〈http://www.fao.org/documents/show_cdr.asp?url_file=/DOCREP/x0172e/x0172e02.htm〉). The shortfall seems enormous. The Udaipur data, which includes other health indicators, suggest that health is definitely reason for concern.

Among the extremely poor in Udaipur, only 57 percent report that the members of their household had enough to eat throughout the year. Among the poor adults in Udaipur, the average "body mass index" (that is, weight in kilograms divided by the square of the height in meters) is 17.8. Sixty-five percent of adult men and 40 percent of adult women have a body mass index below 18.5, the standard cutoff for being underweight (WHO expert consultation, 2004). Moreover, 55 percent of the poor adults in Udaipur are anemic, which means they have an insufficient number of red blood cells. The poor are frequently sick or weak. In Udaipur, 72 percent report at least one symptom of disease and 46 percent report an illness which has left them bedridden or necessitated a visit to the doctor over the last month. Forty-three percent of the adults and 34 percent of the adults aged under 50 report difficulty carrying out at least one of their "activities of daily living," such as working in the field, walking, or drawing water from a well. Diarrhea is extremely frequent among children. About one-seventh of the poor have vision problems, which may be caused by either poor nutrition, or the diseases that afflict them, or a combination of the two. 
Detailed information on health is not available in all the surveys, but most report the incidence over the last month of health episodes that left a household member bedridden for a day or more, or that required a household member to see a doctor. The general pattern is a remarkably high level of morbidity. Among the rural poor living under \$1 a day in Peru, South Africa, East Timor, Panama, and Tanzania, between 11 and 15 percent of households report having a member either being bedridden for at least a day or requiring a doctor. The number is between 21 and 28 percent in Pakistan, Indonesia, and Cote d'Ivoire, and between 35 and 46 percent in Nicaragua, Udaipur, and Mexico.

Even these high numbers may be an understatement if the poor are less prone to recall and report such sicknesses than those with higher incomes. The poor generally do not complain about their health - but then they also do not complain about life in general, either. While the poor certainly feel poor, their levels of self-reported happiness or self-reported health levels are not particularly low (Banerjee, Duflo, and Deaton, 2004). On the other hand, the poor do report being under a great deal of stress, both financial and psychological. In Udaipur, about 12 percent say that there has been a period of one month or more in the last year in which they were so "worried, tense, or anxious" that it interfered with normal activities like sleeping, working, and eating. Case and Deaton (2005) compare data from South Africa to the data from Udaipur and data from the United States. They find that the answers of poor South Africans and poor Indians about stress look very similar, while reported levels of stress are very much lower in the United States. The most frequently cited reason for such tensions is health problems (cited by 29 percent of respondents), with lack of food and death coming next (13 percent each). Over the last year, in 45 percent of the extremely poor households in Udiapur (and 35 percent of those living under $\$ 2$ a day) adults had to cut the size of their meal at some point during the year and in 12 percent of them, children had to cut the size of their meals. In the extremely poor households under $\$ 1$ per day, 37 percent report that, at some point in the past year, the adults in the household went without a meal for an entire day. Cutting meals is also strongly correlated with unhappiness.

Even poor households should be able to save enough to make sure that they never have to cut meals, because as discussed above they do have substantial slack in their budgets and cutting meals is not that common. Additional savings would also make it easier to deal with healthcare emergencies. For these households, saving a bit more would seem like a relatively inexpensive way to reduce stress.

\section{Investment in Education}

The extremely poor spend very little on education. The expenditure on education generally hovers around 2 percent of household budgets: higher in Pakistan ( 3 percent), Indonesia (6 percent), and Cote d'Ivoire (6 percent), but much lower in Guatemala ( 0.1 percent), and South Africa ( 0.8 percent). The fraction does not really change very much when we compare the poor to the extremely poor, or rural areas to urban areas, though in a few countries like Pakistan, urban families spend substantially more than rural families. This low level of expenditure on education is not because the children are out of school. In 12 of the 13 countries in our sample, with the exception of Cote d'Ivoire, at least 50 percent of both boys and girls aged 7 to 12 in extremely poor households are in school. In about half the countries, the proportion enrolled is greater than 75 percent among girls, and more than 80 percent among boys.

The reason education spending is low is that children in poor households typically attend public schools or other schools that do not charge a fee. In countries where poor households spend more on education, it is typically because government schools have fees, as in Indonesia and Cote d'Ivoire. However, mounting evidence, reported below, suggests that public schools in these countries are often dysfunctional, which could explain why even very poor parents in 
Pakistan are pulling their children out of public schools and spending money to send them to private schools.

\section{How the Poor Earn Their Money}

Walking down the main street of the biggest slum in the medium-sized southern Indian city of Guntur at nine in the morning, the first thing one notices are the eateries. In front of every sixth house that directly faced the road, by our count, a woman was sitting behind a little kerosene stove with a round cast-iron griddle roasting on it. Every few minutes someone would walk up to her and order a dosa, the rice and beans pancakes that almost everyone eats for breakfast in south India. She would throw a cupful of the batter on the griddle, swirl it around to cover almost the entire surface, and drizzle some oil around the edges. A minute or two later, she would slide an off-white pock-marked pancake off the griddle, douse it in some sauce, fold it in a newspaper or a banana leaf and hand it to her client, in return for a rupee (roughly 15 cents).

When we walked back down that same street an hour later, the women were gone. We found one inside her house, filling her daughter's plate with lunch that she had cooked while making the dosas. She told us that later that day, she was going out to vend her saris, the long piece of decorative cloth that Indian women drape around themselves. She gets plain nylon saris from the shop and stitches beads and small shiny pieces on them. Once a week, she takes them from house to house, hoping that women would buy them to wear on special occasions. And they do buy them, she said confidently. All the other dosa women we met that day had a similar story: once they are done frying dosas, they do something else. Some collect trash; others make pickles to sell; others work as laborers.

\section{Entrepreneurship and Multiple Occupations among the Poor}

All over the world, a substantial fraction of the poor act as entrepreneurs in the sense of raising capital, carrying out investment, and being the full residual claimants for the resulting earnings. In Peru, 69 percent of the households who live under \$2 a day in urban areas operate a nonagricultural business. In Indonesia, Pakistan, and Nicaragua, the numbers are between 47 and 52 percent. A large fraction of the rural poor operate a farm: 25 to 98 percent of the households who earn less than a dollar a day report being self-employed in agriculture, except in Mexico and South Africa where self-employment in agriculture is very rare. ${ }^{4}$ Moreover, many of the rural poor-from 7 percent in Udaipur up to 36 percent in Panama-also operate a nonagricultural business.

Many poor households have multiple occupations. Like the dosa women of Guntur, 21 percent of the households living under $\$ 2$ a day in Hyderabad who have a business actually have more than one, while another 13 percent have both a business and a laborer's job. This multiplicity of occupations in urban areas is found in many other countries as well, though not everywhere. Among those earning less than $\$ 2$ a day, 47 percent of the urban households in Cote d'Ivoire and Indonesia get their income from more than one source; 36 percent in Pakistan; 20.5 percent in Peru; and 24 percent in Mexico. However, in urban South Africa and Panama, almost no one has more than one occupation and only 9 percent do so in Nicaragua and Timor Leste. 5

This pattern of multiple occupations is stronger in rural areas. In Udaipur district, as we discussed earlier, almost everybody owns some land and almost everybody does at least some

\footnotetext{
${ }^{4}$ The low level of agriculture among the extremely poor in South Africa is easily explained. The black population, which contains almost all of the extremely poor people, was historically under the apartheid regime not allowed to own land outside the "homelands," and most of the land in the homelands was not worth cultivating.

${ }^{5}$ This result may reflect a data problem. Anthropologists do claim that they observe multiple occupations in South African households (Francie Lund, verbal communication to Angus Deaton).
} 
agriculture. Yet only 19 percent of the households describe self-employment in agriculture as the main source of their income. Working on someone else's land is even rarer, with only 1 percent reporting this as their main source of income. In other words, the poor cultivate the land they own, no less and usually, no more. Yet, agriculture is not the mainstay of most of these households. The most common occupation for the poor in Udaipur is working as a daily laborer: 98 percent of households living under $\$ 1$ per day in rural areas report doing this, and 74 percent claim it is their main source of earnings.

This pattern is confirmed by data from a smaller survey of 27 villages randomly sampled from eight districts in West Bengal (Banerjee, 2006). In this survey, even households that claim to be the operators for a plot of land spend only 40 percent of their time in agricultural activities on their own land. The fraction is not very different for men and women-women do less direct agricultural work but more animal rearing, along with growing fruits and vegetables. Their other activities include teaching, sewing and embroidery, unpaid household work, and gathering fuel. Strikingly, almost 10 percent of the time of the average household is spent on gathering fuel, either for use at home or for sale. The median family in this survey has three working members and seven occupations.

In most of the Living Standard Measurement Surveys, households are not asked their main source of earnings, but the pattern of diversification among rural households is apparent nevertheless. In Guatemala, 65 percent of the rural extremely poor say they get some income from self-employment in agriculture, 86 percent work as laborers outside agriculture, and 24 percent are self-employed outside agriculture. In Indonesia, 34 percent of the rural, extremely poor households work as laborers outside of agriculture, and 37 percent earn income from selfemployment outside of agriculture. In Pakistan, 51 percent of the rural, extremely poor earn income from labor outside of agriculture and 35 percent from a business outside of agriculture. Overall, the fraction of the rural extremely poor households who report that they conduct more than one type of activity to earn a living is 50 percent in Indonesia, 72 percent in Cote d'Ivoire, 84 percent in Guatemala, and 94 percent in Udaipur. It is smaller, but not negligible-between 10 and 20 percent - in Nicaragua, Panama, Timor Leste, and Mexico. Once again, an exception to this general pattern is South Africa, where less than 1 percent of the rural poor or extremely poor report multiple occupations.

\section{Temporary Migration to Work}

Where do rural households, which are often a walk of a half-hour or more from the nearest road, find all this nonagricultural work? They migrate.

Temporary migration is rarely documented in surveys, but in the Udaipur survey, which had questions about this activity, 60 percent of the poorest households report that someone from their family had lived outside for a part of the year to obtain work. For 58 percent of the families, the head of the household had migrated. The migrants typically complete multiple trips in a year. However, people do not leave for very long. The median length of a completed migration is one month, and only 10 percent of migration episodes exceed three months. Nor do most of the migrants travel very far: 28 percent stay in the district of Udaipur and only 42 percent leave the state of Rajasthan.

Permanent migration for work reasons is rare, although many women move when they marry. Even if we look at households currently living in urban areas, where the inflow of immigrants is presumably higher than in rural areas, the share of extremely poor households who had one member that was born elsewhere and had migrated for work reasons was just 4 percent in Pakistan, 6 percent in Cote d'Ivoire, 6 percent in Nicaragua, and almost 10 percent in Peru. The 1991 Census of India reports that only 14.7 percent of the male population lives somewhere other than where they were born. Indonesia is the only country in our data where the proportion 
is higher: 41 percent of the urban households came from elsewhere. Indonesia is also the only country in this sample where migration was explicitly subsidized.

\section{Lack of Specialization}

A pattern seems to emerge. Poor families do seek out economic opportunities, but they tend not to become too specialized. They do some agriculture, but not to the point where it would afford them a full living (for example, by buying/renting/sharecropping more land). They also work outside, but only in short bursts, and they do not move permanently to their place of occupation.

This lack of specialization has its costs. Many of these poor households receive most of their earnings from these outside jobs, despite only being away for 18 weeks of the year on average (in the case of Udaipur). As short-term migrants, they have little chance of learning their jobs better, or ending up in a job that suits their specific talents, or being promoted.

Even the nonagricultural businesses that the poor operate typically require relatively few specific skills. For example, the businesses in Hyderabad include 11 percent tailors, 8 percent fruit and vegetable sellers, 17 percent small general stores, 6.6 percent telephone booths, 4.3 percent auto owners, and 6.3 percent milk sellers. Except for tailoring, none of these jobs require the high levels of specialized competence that take a long time to acquire, and therefore are associated with higher earnings. In several ways, the poor are trading off opportunities to have higher incomes.

\section{The Problem of Scale}

The businesses of the poor typically operate at a remarkably small scale. As we saw, the average landholding for those who own land is usually quite tiny, and renting land is infrequent. Furthermore, most of this land is not irrigated and cannot be used all year.

The scale of nonagricultural businesses run by the poor also tends to be small. In the 13 countries in our sample, the median business operated by people living under $\$ 2$ dollars a day either in a rural or an urban location has no paid staff, and the average number of paid employees range between 0.14 in rural Nicaragua to 0.53 in urban Panama. Businesses are operated on average by 1.38 (in Peru) to 2.59 (in Cote d'Ivoire) people-most of them being family members. Most of these businesses have very few assets as well. In Hyderabad, only 20 percent of the businesses operate out of a separate room. In Pakistan, about 40 percent of the businesses of those living under $\$ 1$ or $\$ 2$ dollar a day have a vehicle, but only 4 percent have a motorized vehicle and none have any machinery. In other countries, even nonmotorized vehicles are rare. In Hyderabad, where we have an exhaustive list of business assets, the most common assets are tables, scales, and pushcarts.

Many of these businesses are probably operating at too small a scale for efficiency. The women making dosas spend a lot of time waiting: having fewer dosa-makers who do less waiting would be more efficient. In fact, it might make sense in efficiency terms for the dosa-makers to work in pairs: one to make the dosas and one to wrap them and make change.

\section{Markets and the Economic Environment of the Poor}

The economic choices of the poor are constrained by their market environment. For example, some may save little because they lack a safe place to put their savings. Other constraints result from a lack of shared infrastructure. When the government builds a water line to your neighborhood, for example, you no longer need your own well. This section focuses on markets. The next takes up the issue of infrastructure. 


\section{The Market for Credit and the Poor}

The data from our 13 countries suggests that the fraction of rural, extremely poor households having an outstanding debt varies between countries, from 11 percent in rural East Timor to 93 percent in Pakistan. But across the surveys, very few of the poor households get loans from a formal lending source.

In the Udaipur sample, about two-thirds of the poor had a loan at the time of the interview. Of these loans, 23 percent are from a relative, 18 percent from a money lender, 37 percent from a shopkeeper, and only 6.4 percent from a formal source like a commercial bank or a cooperative. Lest one suspect that the low share of bank credit is due to the lack of physical access to banks, a similar pattern occurs in urban Hyderabad, where households living below $\$ 2$ a day primarily borrow from moneylenders (52 percent), friends or neighbors ( 24 percent), and family members ( 13 percent), and only 5 percent of the loans are with commercial banks. Indonesia is the one country where a substantial share of loans to the poor is formal: thanks to efforts by the Bank Rakyat Indonesia, one-third of the rural poor Indonesian households borrow from a bank. In the other countries, relatives, shopkeepers, and other villagers form, by far, the overwhelming source of borrowed funds.

Credit from informal sources tends to be expensive. In the Udaipur survey, where we have data on interest rates not available in other surveys, those living on less than $\$ 1$ a day pay on average 3.84 percent per month for the credit they receive from informal sources. Those who consume between $\$ 1$ and $\$ 2$ dollar a day per capita pay a little less: 3.13 percent per month. This lower rate occurs in part because they rely less on informal sources of credit and more on the formal sources than the extremely poor; and in part it reflects that informal interest rates are lower for those with more land - the interest rate from informal sources drops by 0.40 percent per month for each additional hectare of land owned. The monthly interest rate we see in the Hyderabad sample is even higher: 3.94 percent per month for those living under \$2 dollars a day. Few of these urban poor borrowers in Hyderabad have any land to use as collateral.

These high interest rates seem not to occur directly because of high rates of default, but rather as a result of the high costs of contract enforcement. While delay in repayment of informal loans is frequent, default is actually rare (Banerjee and Duflo, 2005). For example, a "Summary Report on Informal Credit Markets in India" reports that across four case studies of moneylenders in rural India, default explains only 23 percent of the interest rate charged (Dasgupta, 1989). A well-known study of rural money-lenders in Pakistan found that the median rate of default across money-lenders is just 2 percent (Aleem, 1990).

However, these low default rates are anything but automatic. Contract enforcement in developing countries is often difficult, and courts often fail to punish recalcitrant borrowers. As a result, lenders often must spend resources to assure that their loans get repaid, which drives up interest rates. The fact that lending depends so much on effective screening and monitoring also means that lending to the poor is especially difficult. Again, part of the problem is that the poor lack collateral to secure the loan and therefore lenders hesitate to trust them. Given that the loan amount will in any case be small, the profits from the transaction may not be large enough to cover the cost of monitoring/screening. As a result, many lenders are reluctant to lend to the poor. Moreover, informal lenders located close to the borrowers may be the only ones who are willing to lend to the poor-since monitoring/screening is relatively cheap for them. However, these informal lenders pay more for their deposits than the more formal institutions, since they are less capitalized and regulated and do not have any government guarantees. This higher cost of deposits is passed on to poorer borrowers. The gap can be considerable-in the study by Aleem (1990), the cost of capital for the money-lenders was 32.5 percent in a year when banks were only paying 10 percent for their deposits. 


\section{The Market for Savings and the Poor}

A main challenge for the poor who try to save is to find safety and a reasonable return. Stashing cash inside your pillow or elsewhere at home is neither safe nor well-protected from inflation. In addition, recent research by Ashraf, Karlan, and Yin (forthcoming) in the Philippines and Duflo, Kremer, and Robinson in Kenya (2006) suggests that the poor, like everyone else, have problems resisting the temptation of spending money that they have at hand.

Few poor households have savings accounts. Except in Cote d'Ivoire, where 79 percent of the extremely poor households under $\$ 1$ a day have a savings account, the fraction is below 14 percent in the other countries in our data. In Panama and Peru, less than 1 percent of poor households have a savings account. In most countries, the share of households with a saving account is similar in rural and urban areas, and similar for those under $\$ 2$ a day and those under $\$ 1$ a day. Here India appears to be an exception, since only 6 percent of the extremely poor households in rural Udaipur have a savings account, while 25 percent of them do in the city of Hyderabad.

A lack of access to reliable savings accounts appears common to the poor everywhere, as documented in Stuart Rutherford's (2000) fascinating book, The Poor and their Money. Rutherford describes many strategies the poor use to deal with this problem. For example, they form savings "clubs," where each person makes sure that the others save. Self-Help Groups (SHGs), popular in parts of India and present in Indonesia as well, are saving clubs which also make loans to their members out of the accumulated savings (they are also sometimes linked to banks). In Africa, Rotating Savings and Credit Associations (ROSCAs) allow people to lend their savings to each other on a rotating basis. Others pay deposit collectors to collect their deposits and put them in a bank. Others deposit their savings with local money-lenders, with credit unions (which are essentially larger and much more formally organized self-help groups) or in an account at the local post office. Indeed, one reason why many of the poor respond so well to microcredit is not necessarily because it offers them credit, but because once you take a loan and buy something with it, you have a disciplined way to save-namely, by paying down the loan.

Even participation in semiformal savings institutions (such as self-help groups, ROSCAs, and microfinance institutions) is not nearly as common among the poor as one might have expected. Even in India, despite the high visibility especially of SHGs, less than 10 percent of the poor in our Udaipur and Hyderabad surveys are part of an SHG or a ROSCA. The majority of the households who have any savings deposit it at a bank.

\section{The Market for Insurance and the Poor}

The poor have little access to formal insurance. In many surveys, questions about insurance are not even asked. In the six of our seven countries where such data is available, less than 6 percent of the extremely poor are covered by health insurance of any kind. The exception is Mexico, where about half of the extremely poor have coverage. The numbers are not much higher in urban areas. Life insurance is a bit more common in India (and is, essentially, a form of savings). Four percent of the extremely poor in Udaipur and 10 percent in Hyderabad have life insurance. ${ }^{6}$

In principle, social networks can provide informal insurance. For example, Udry (1990) shows that poor villagers in Nigeria experience a dense network of loan exchanges: Over the course of one year, 75 percent of the households had made loans, 65 percent had borrowed money,

\footnotetext{
${ }^{6}$ Surprisingly, weather insurance is also essentially absent everywhere the world over (Morduch, 2006), although it would seem straightforward to provide insurance against observed weather patterns.
} 
and 50 percent had been both borrowers and lenders. Almost all of these loans took place between neighbors and relatives. Both the repayment schedule and the amount repaid were affected by both the lender's and the borrower's current economic conditions, underlining the role of these informal loans in providing insurance. Munshi and Rosenzweig (2005) argue that the same process happens in India through the jati or subcaste networks.

Yet these informal networks have only a limited ability to protect the households against risk. The consumption of poor households is strongly affected by variations in their incomes, as has been shown by Deaton (1997) in Cote d'Ivoire, Munshi and Rosenzweig (2005) in India, Fafchamps and Lund (2003) in the Philippines, and Townsend (1995) in Thailand. Poor households also bear most health care risks (both expenditures and foregone earnings) directly. For example, Gertler and Gruber (2002) find that in Indonesia a decline in the health index of the head of the household is associated with a decline in nonmedical expenditures. In Udaipur, large expenditures on health ( $\$ 70$ and higher, at purchasing power parity exchange rates) are covered by borrowing or dissaving. Only 2 percent of these expenses were paid for by someone else, and none came from the self-help groups. Twenty-four percent of the households in Hyderabad had to borrow to pay for health expenses in the last year. When the poor fall under economic stress, their "insurance" often means eating less or taking their children out of school. For example, Jacoby and Skoufias (1997) find that poor children leave school in bad years. Rose (1999) finds that the gap in mortality of girls relative to boys is much larger in drought years (but only for the landless households, who are not able to sell land or borrow to weather the crisis). Poor households also are less likely to get medical treatment for themselves or their children. In the Udaipur sample, those who were sick in the last months and did not seek treatment (more than half) cite lack of money more often than any other reason (34 percent). The lack of insurance also leads the poor to underinvest in risky but profitable technologies, such as new seeds (Morduch, 1995).

The weaknesses of informal insurance should not really be a surprise. Ultimately, informal insurance relies on the willingness of the fortunate to take care of those less favored, which limits the insurance provided. Moreover, informal social networks are often not welldiversified. They often spread risk over households who live nearby and have similar incomes and occupations, as Fafchamps and Gubert (2005) show for the Philippines.

Governments in these countries are not very effective at providing insurance either. In most countries, the government is supposed to provide free health care to the poor. Yet health care is rarely free. Government health care providers often illegally charge for their own services and for medicines. Also, as we will see, the quality of care in the public system is so low that the poor often end up visiting private providers.

A number of governments provide a form of income insurance through safety-net "food for work" programs. Under these programs, everyone is entitled to a certain number of days of government employment usually involving physical labor at a pre-announced (relatively low) wage. In Udaipur, where the years leading up to the survey had been particularly arid, 76 percent of the poor had at least one of the household members work on a public employment program of this kind. However, such schemes often offer only a limited number of jobs which can end up being doled out in a way that discriminates against the poor.

\section{The Market for Land and the Poor}

For historical reasons, land is the one asset the poor tend to own. But land records in developing countries are often incomplete and many people do not have titles to their land. As many including most famously Hernando De Soto (2003) have emphasized, an unclear title makes it harder to sell the land or mortgage it. This situation is especially troubling for the poor, because they tend to own a lot of the land that was either recently cleared or recently encroached 
upon, which is typically the land where tilling is incomplete. Erica Field (2006) suggests that, in Peru, the poor spend a lot of time protecting their claims to the land (since they have no title, they have no legal recourse).

The poor also suffer because where titles are missing or imperfectly enforced, political influence matters. In parts of Ghana, land belongs either to lineages or to the village, and cultivators have only rights of use. In this context, Goldstein and Udry (2005) show that the people who lack the political clout to prevent having their land taken away from them by the village or their lineage (which typically includes the poor) do not leave their land fallow for long enough. Leaving land to fallow increases its productivity, but increases the risk that someone may seize it.

Finally, a long tradition of research in agricultural economics argues that the poor lack incentives to make the best use of the land they are cultivating because they are agents rather than owners (Shaban, 1987). Banerjee, Gertler, and Ghatak (2002) found that a reform of tenancy that forced landlords to raise the share of output going to the sharecroppers and also gave them a secure right to the land raised productivity by about 50 percent.

\section{Infrastructure and the Economic Environment of the Poor}

Infrastructure includes roads, power connections, schools, health facilities, and public health infrastructure (mostly water and sanitation). While markets and the government play differing roles in the supply of such infrastructure, all elements of infrastructure are usefully thought of as part of the environment in which people live, with some characteristics of a local public good, rather than something that can be purchased piecemeal by individuals.

The availability of physical infrastructure to the poor like electricity, tap water, and even basic sanitation (like access to a latrine) varies enormously across countries. In our sample of 13 countries, the number of rural poor households with access to tap water varies from none in Udaipur to 36 percent in Guatemala. The availability of electricity varies from 1.3 percent in Tanzania to 99 percent in Mexico. The availability of a latrine varies from none in Udaipur to 100 percent in Nicaragua. Different kinds of infrastructure do not always appear together. In Indonesia, 97 percent of rural, extremely poor households have electricity but only 6 percent have tap water. Some governments provide reasonable access to both electricity and tap water to the extremely poor: in Guatemala, 38 percent of the extremely poor rural households have tap water and 30 percent have electricity. Other governments do very little: in Udaipur, Papua New Guinea, East Timor, and South Africa, the share of the rural, extremely poor with tap water or electricity is below 5 percent.

Generally, access to electricity and tap water is greater for the urban poor than the rural poor (which is probably fortunate since lack of sanitation in very dense surroundings can be particularly dangerous from the public health point of view). The only exception to this pattern in our 13 countries is Cote d'Ivoire, where rural households seem to have better access. Moreover, access to both tap water and electricity is typically higher for those under $\$ 2$ a day than those under $\$ 1$ a day.

Most low-income countries have made some attempt to ensure that poor households have access to primary schools and basic health centers. For example, most Indian villages now have a school within a kilometer, and a health subcenter exists for every 10,000 people. However, the quality of the facilities that serve the poor tends to be low, even when they are available, and it is not clear how much they actually deliver. Chaudhury, Hammer, Kremer, Muralidharan, and Rogers (2005) report results on surveys they conducted to measure the absence of teachers and health workers in Bangladesh, Ecuador, India, Indonesia, Peru, and Uganda. They found that the average absence rate among teachers is 19 percent and the average absence rate among 
health workers is 35 percent. Moreover, because not all teachers and health workers are actually working when at their post, even this picture may be too favorable. Moreover, absence rates are generally higher in poor regions.

In an innovative study on health care quality, Das and Hammer (2004) collected data on the competence of doctors in Delhi, India, based on the kinds of questions they ask and the action they say they would take faced with a hypothetical patient, suffering from conditions they are likely to encounter in their practice. Every Delhi neighborhood, poor or rich, lives within 15 minutes of at least 70 health providers. However, the gap in competence of the average health practitioner between the poorest and richest neighborhoods is almost as large as the gap between the competence of a health provider with an MBBS degree (the equivalent of an MD in the United States) and a provider without such a qualification. In fact, an expert panel found that the treatments suggested by the average provider in their sample are slightly more likely to do harm rather than good, due to a combination of misdiagnosis and overmedication.

These differences in health care and basic sanitation infrastructure can affect mortality. Several surveys ask women about their pregnancies and the outcomes, including whether the child is still alive. We compute an infant mortality measure as the number of children who died before the age of one divided by the number of live births. The numbers are startling, especially because they are likely to be underestimates (not all children are remembered, especially if they died very early). Among the rural, extremely poor, the lowest infant mortality that we observe is 3.4 percent in Indonesia. At the high end, infant mortality among the extremely poor is 8.7 percent in South Africa and Tanzania, 10 percent in Udaipur, and 16.7 percent in Pakistan. The rates are lower, but not much lower, in urban areas. The rates also remain high if the definition of poverty is expanded to include those who live under $\$ 2$ a day. Wagstaff (2003) uses data from the demographic and health surveys to estimate prevalence of malnutrition and child mortality among those living under $\$ 1$ a day in a number of countries. He finds very large difference between survival chances of poor children in different countries, and shows that they are correlated with health spending per capita in these countries.

The low quality of teaching in public schools has clear effect on learning levels as well. In India, despite the fact that 93.4 percent of children ages 6-14 are enrolled in schools ( 75 percent of them in government schools), a recent nationwide survey found that 34.9 percent of the children age 7 to 14 cannot read a simple paragraph at second-grade level (Pratham, 2006). Moreover, 41.1 percent cannot do subtraction, and 65.5 percent cannot do division. Even among children in grades six to eight in government schools, 22 percent cannot read a secondgrade text.

In countries where the public provision of education and health services is particularly low, private providers have stepped in. In the parts of India where public school teacher absenteeism is the highest, the fraction of rural children attending private schools is also the highest (Chaudhury, Hammer, Kremer, Muralidharan, and Rogers, 2005). However, these private schools are less than ideal: they have lower teacher absenteeism than the public schools in the same village, but their teachers are significantly less qualified in the sense of having a formal teaching degree.

A similar but more extreme pattern arises in health care. Again, private providers who serve the poor are less likely to be absent and more likely to examine the patient with some care than their public counterparts, but they tend to be less well qualified (for example, Das and Hammer, 2004). However, unlike in education, where most poor children are still in the public system, even in countries and regions where public education is of extremely poor quality, where the public health care system has high levels of absence, most people actually go to private providers. For example, in India, where absence of health care providers is 40 percent, 58 
percent of the extremely poor households have visited a private health care provider in the last month. By contrast in Peru, where the absentee rate for health care providers is fairly low at 25 percent (Chaudhury, Hammer, Kremer, Muralidharan, and Rogers, 2005), only 9 percent of the rural extremely poor households have been to a private health provider in the last month. Within the Udaipur District, Banerjee, Deaton, and Duflo (2004) also found that the rate of usage of the public health facility is strongly correlated with the absence rate at the public health facilities in the areas.

\section{Understanding the Economic Lives of the Poor}

Many facts about the lives of the poor start to make much more sense once we recognize that they have very limited access to efficient markets and quality infrastructure. The fact that the poor usually cultivate the land they own, no more and no less, for example, probably owes a lot to the agency problems associated with renting out land. In part, it must also reflect the fact that the poor, who typically own too little land relative to the amount of family labor, suffer from lack of access to credit. This pattern is reinforced by the difficulties that the poor face in getting any kind of insurance against the many risks with which a farmer needs to deal: A second job outside agriculture offers security against some of that risk.

\section{Why So Little Specialization?}

Risk-spreading is clearly one reason why the poor, who might find risk especially hard to bear, tend not to be too specialized in any one occupation. They work part time outside agriculture to reduce their exposure to farming risk, and keep a foot in agriculture to avoid being too dependent on their nonagricultural jobs.

Another reason for a second job is to occupy what would otherwise be wasted time. When we asked the dosa-sellers of Guntur why they did so many other things as well, they all said: "[We] can sell dosas in the morning. What do we do for the rest of the day?" Similarly, farmers who do not have irrigated land can only farm when the land is not too dry. Finding some work outside agriculture is a way for them to make productive use of their time when the land is unusable. However, this argument is incomplete. We also need to explain what made the women opt to sell dosas: After all they could have skipped the dosas and specialized in whatever they were doing for the rest of the day. Risk spreading remains a possible answer, but many of them seem to be in relatively safe occupations. Given the fact that almost everyone owns the cooking implement that one needs to make a dosa and entry is free, it does not seem that $d o s a$-making is an extraordinarily profitable activity.

A final, more compelling reason for multiple jobs is that the poor cannot raise the capital they would need to run a business that would occupy them fully. As we saw, most businesses operate with very little assets and little working capital. Likewise, some poor farmers might be able to irrigate their lands and make them useable for a larger part of the year, but they lack the necessary access to funds. Of course, in agriculture, some downtime will always remain, justifying some amount of diversification of jobs. But such downtime would be much more limited than what the data actually reveals.

\section{Why So Many Entrepreneurs?}

Once we draw this link between the tendency of the poor to be in multiple occupations and their access to financial markets, it is clear why so many of the poor are entrepreneurs. If you have few skills and little capital, and especially if you are a woman, being an entrepreneur is often easier than finding an employer with a job to offer. You buy some fruits and vegetables or some plastic toys at the wholesalers and start selling them on the street; you make some extra dosa mix and sell the dosas in front of your house; you collect cow dung and dry it to 
sell it as a fuel; you attend to one cow and collect the milk. These types of activities are exactly those in which the poor are involved.

It is important not to romanticize these penniless entrepreneurs. Given that they have no money, borrowing is risky, and no one wants to lend to them, the businesses they run are inevitably extremely small, to the point where there are clearly unrealized economies of scale. Moreover, given that so many of these firms have more family labor available to them than they can use, they do very little to create jobs for others. Of course, this pattern makes it harder for anyone to find a job and hence reinforces the proliferation of petty entrepreneurs.

\section{Why Don't the Poor Eat More?}

Another puzzle is why the poor do not spend more on food both on average and especially out of the marginal dollar. Eating more and eating better (more grains and iron-rich foods, less sugar) would help them build their body-mass indices to healthier levels.

One possibility is that eating more would not help them that much, or not for long, because they would become weak again at the first attack of disease, which will invariably occur. For example, Deaton, Cutler, and Lleras-Muney (2006) argue that nutrition is at best a very small part of what explains the tremendous gains in health around the world in the past few decades. However, some improvements in nutrition (reduction of anemia in particular) have been linked to increased productivity (Thomas et al., 2004). Moreover, as we saw, not having enough to eat does, at a minimum, make the poor extremely unhappy.

Provided that eating more would increase their productivity, it is unlikely that the low levels of good consumption can be explained by a simple lack of self control (that is, the poor cannot resist temptations to spend on things other than food). As we noted above, the poor also spend surprisingly large amounts on entertainment: televisions, weddings, or festivals. All of these involve spending a large amount at one time, which implies some saving unless they happen to be especially credit-worthy. In other words, many poor people save money that they could have eaten today to spend more on entertainment in the future, which does not immediately fit the idea that they lack self-control.

The need to spend more on entertainment rather than on food appears to be a strongly felt need, not a result of inadequate planning. One reason this might be the case is that the poor want to keep up with their neighbors. Fafchamps and Shilpi (2006) offer evidence from Nepal in which people were asked to assess whether their level of income as well as their levels of consumption of housing, food, clothing, health care, and schooling were adequate. The answers to these questions were strongly negatively related to the average consumption of the other people living in the same village.

\section{Why Don't the Poor Invest More in Education?}

The children of the poor are, by and large, going to primary school. However, parents are not reacting to the low quality of these schools, either by sending their children to better and more expensive schools or by putting pressure on the government to do something about quality in government schools. Why not?

One reason is that poor parents, who may often be illiterate themselves, may have a hard time recognizing that their children are not learning much. Poor parents in Eastern Uttar Pradesh in India have limited success in predicting whether their school-age children can read (Banerjee et al., 2006). Moreover, how can parents be confident that a private school would offer a better education, given that the teacher there is usually less qualified than the public school teachers? After all, researchers have only discovered this pattern in the last few years. As for putting 
pressure on the government, it is not clear that the average villager would know how to organize and do so.

\section{Why Don't the Poor Save More?}

The arguments based on lack of access to credit and insurance or labor market rigidities, by themselves, do not help very much in understanding why the poor are not more interested in accumulating wealth. After all, the poor could easily save more without getting less nutrition, by spending less on alcohol, tobacco, festivals, and food items such as sugar, spice, and tea.

It is true that the poor typically have no bank accounts or other financial assets with which to save, but many of them have their own businesses, and these tend to be chronically underfunded. So why not save up to buy a new machine, or increase the stock in the shop? Moreover, as we saw above, a very substantial fraction of the poor have debt, and the interest rate on the debt often exceeds 3 percent per month. Paying down debt is therefore a very attractive way to save. Even if you have no business to grow, and have no debt to repay, just holding some extra stocks for the proverbial rainy day (or "the drought") can save both worry and the misery of watching your children go hungry. In other words, precautionary motives for saving should be especially strong for the poor.

Part of the answer is probably that saving at home is hard. The money may be stolen (especially if you live in a house that cannot be locked) or grabbed by your spouse or your son. Also, if you have money at hand, you are constantly resisting temptation to spend: to buy something, to help someone to whom you find it difficult to say "no," to give your child a treat. Such temptations may be especially hard for the poor, because many of the temptations they are resisting are things that everyone else might take for granted.

The poor seem aware of their vulnerability to temptation. In the Hyderabad survey, the respondents were asked to name whether they would like to cut particular expenses, and 28 percent of the poor named at least one item. The top item that households would like to cut is alcohol and tobacco (mentioned by 44 percent of the households that want to cut on items). Then came sugar, tea, and snacks ( 9 percent), festivals ( 7 percent), and entertainment ( 7 percent).

Self-knowledge does not help in addressing self-control problems; in fact, self-knowledge about a lack of self-control means that you know your saving will probably just end up feeding some future indefensible craving, and the machine for which you are trying to save will never actually be bought. Being naïve might actually help-you might be lucky and save enough to buy the machine before the temptation gets to you.

\section{Beyond Market Failures and Self-control Problems}

An interesting example that spans many of the arguments we have used above is a study by Duflo, Kremer, and Robinson (2006) on investment in fertilizer in Kenya. According to surveys conducted over several years, just 40.3 percent of farmers had ever used fertilizer, and just 25 percent used fertilizer in any given year. Conservative estimates suggest that the average return to using fertilizer exceeds 100 percent, and the median return is above 75 percent. Duflo, Kremer, and Robinson conducted field trials of fertilizer on the farms of actual randomly selected farmers, which were meant to teach the farmers how to use fertilizer and the rewards of doing so. They found that the farmers who participated in the study are 10 percent more likely on average to use fertilizer in the very next season after the study, but only 10 percent more likely — and the effects fade after the first season.

When farmers were asked why they did not use fertilizer, most farmers replied that they did not have enough money. However, fertilizer can be purchased (and used) in small quantities, 
so this investment opportunity seems accessible to farmers with even a small level of saving. The main issue, once again, appears to be that farmers find it difficult to save even small sums of money. The program in Kenya offered to sell farmers a voucher right after the harvest, which is when farmers have money in hand, which would entitle them to buy fertilizer later.

This program had a large effect: 39 percent of the farmers offered the voucher bought the fertilizer; the effects are as large as a 50 percent subsidy on the cost of fertilizer. The voucher seemed to work as a commitment device to encourage saving. But a puzzle remains: farmers could have bought the fertilizer in advance on their own. Indeed, a huge majority of the farmers who bought the vouchers for future delivery of fertilizer requested immediate delivery, and then stored the fertilizer for later use. Moreover, almost all of them used the fertilizer they bought. They apparently had no self-control problems in keeping the fertilizer, even though they could easily exchange the fertilizer for something more immediately consumable.

\section{Why Don't the Poor Migrate for Longer?}

A final puzzle is why the poor do not migrate for longer periods, given that they could easily earn much more by doing so. Munshi and Rosenzweig (2005) argue that the lack of long-term migration reflects the value of remaining close to one's social network in a setting where the social network might be the only source of (informal) insurance available to people. Those who migrate for short periods of up to a few months leave their entire family, who presumably can maintain their social links, behind. However, the ultimate reason seems to be that making more money is not a huge priority, or at least not a large enough priority to experience several months of living alone and often sleeping on the ground in or around the work premises.

In some ways this puzzle resembles the question of why the Kenyan farmers do not buy fertilizer right after the harvest even though they are happy to buy (and use it) if someone made the (small) effort to bring it to their farm. In both cases, one senses a reluctance of poor people to commit themselves psychologically to a project of making more money. Perhaps at some level this avoidance is emotionally wise: thinking about the economic problems of life must make it harder to avoid confronting the sheer inadequacy of the standard of living faced by the extremely poor.

\section{Acknowledgements}

We thank Andrei Shleifer for motivating us to undertake this exercise. We thank him and the editors of this journal for detailed suggestions on the previous draft of this paper. We thank Danielle Li, Marc Shotland, and Stefanie Stancheva for spectacular assistance in assembling the data, and Kudzai Takavarasha for carefully editing a previous draft. Special thanks to Angus Deaton for extremely useful advice and guidance and extensive comments on the previous draft and to Gary Becker for helpful comments.

\section{References}

Aleem, Irfan. Imperfect Information, Screening and the Costs of Informal Lending: A Study of a Rural Credit Market in Pakistan. World Bank Economic Review 1990;4(3):329-349.

Ashraf, Nava; Karlan, Dean; Yin, Wesley. Tying Odysseus to the Mast: Evidence from a Commitment Savings Product in the Philippines. Quarterly Journal of Economics. Forthcoming

Audretsh, David. The Entrepreneurial Society. Oxford: Oxford University Press, Inc.; 2005.

Banerjee, Abhijit; Deaton, Angus; Duflo, Esther. Wealth, Health, and Health Services in Rural Rajasthan. American Economic Review 2004;94(2):326-330.

Banerjee, Abhijit; Duflo, Esther. Handbook of Economic Growth, Volume 1A, ed. Steve Durlauf and Philippe Aghion. Amsterdam: Elsevier Science; 2005. Growth Theory through the Lens of Development Economics; p. 473-552.

Banerjee, Abhijit; Duflo, Esther; Glennerster, Rachel. A Snapshot of Micro Enterprises in Hyderabad. 2006Unpublished paper, MIT 
Banerjee, Abhijit; Gertler, Paul; Ghatak, Maitreesh. Empowerment and Efficiency: Tenancy Reform in West Bengal. Journal of Political Economy 2002;110(2):239-280.

Banerjee, Abhijit; Somanathan, Rohini. The Political Economy of Public Goods: Some Evidence from India. 2005. http://econ-www.mit-.edu/faculty/download_pdf.php?id=1144

Banerjee, Abhijit; Barnerji, Rukmini; Duflo, Esther; Glennerster, Rachel; Keniston, Daniel; Khemani, Stuti; Shotland, Marc. Can Information Campaigns Raise Awareness and Local Participation in Primary Education? A Study of Jaupur District in Uttar Pradesh. 2006.

http://econ-www.mit.edu/faculty/download_pdf.php?id=1425

Banerjee, Nirmala. A Survey of Occupations and Livelihoods of Households in West Bengal". 2006Sachetana. Unpublished paper

Case, Anne; Angus, Deaton. Health and Wealth among the Poor: India and South Africa Compared. American Economic Review Papers and Proceedings 2005;95(2):229-233.

Chaudhury, Nazmul; Hammer, Jeffrey; Kremer, Michael; Muralidharan, Karthik; Rogers, F Halsey. Teacher Absence in India: A Snapshot. Journal of the European Economic Association 2005 AprilMay;3(2-3):658-667.

Das, Jishnu; Hammer, Jeffrey. Strained Mercy: The Quality of Medical Care in Delhi. Economic and Political Weekly 2004 February 28;39(9):951-965.

Dasgupta, A. Reports on Credit Markets in India: Summary. Technical Report. New Delhi: National Institute of Public Finance and Policy; 1989.

Dasgupta, Partha; Ray, Debraj. Inequality as a Determinant of Malnutrition and Unemployment: Policy. Economic Journal 1986;96(384):1011-1034.

Deaton, Angus. The Analysis of Household Surveys: A Microeconometric Approach to Development Policy. Baltimore: Johns Hopkins University Press for the World Bank; 1997.

Deaton, Angus. Measuring poverty. In: Banerjee, Abhijit; Benabou, Roland; Mookherjee, Dilip, editors. Understanding Poverty. Oxford University Press: 2004.

Deaton, Angus. Purchasing Power Parity Exchange Rates for the poor: Using Household Surveys to Construct PPPs. 2006. http://www.princeton.edu/ rpds/downloads/Deaton_PPPP_version_aug_06.pdf

Deaton, Angus; Subramanian, Shankar. The Demand for Food and Calories. Journal of Political Economy 1996;104(1):133-162.

Deaton, Angus; Cutler, David; Lleras-Muney, Adriana. The Determinants of Mortality. Journal of Economic Perspectives 2006 Summer;20(3):97-120.

Duflo, Esther; Kremer, Michael; Robinson, Jonathan. Why Don't Farmers use Fertilizer: Evidence from Field Experiments. 2006Unpublished paper, MIT

Fafchamps, Marcel; Lund, Susan. Risk-Sharing Networks in Rural Philippines. Journal of Development Economics 2003;71(2):261-287.

Fafchamps, Marcel; Gubert, Flore. Working Papers DT/2005/13. DIAL (Développement, Institutions \& Analyses de Long terme); 2005. The Formation of Risk Sharing Networks.

Fafchamps, Marcel; Shilpi, Forhad. Subjective Welfare, Isolation, and Relative Consumption. 2006. http://www.economics.ox.ac.uk/members/marcel.fafchamps/homepage/nepwel.pdf"

Field, Erica. Entitled to Work: Urban Property Rights and the Labor Supply in Peru. 2006. http://www.economics.harvard.edu/faculty/field/papers/Field_COFOPRI.pdf

Filmer, Deon; Pritchett, Lant. Estimating Wealth Effects without Expenditure Data-or Tears: An Application to Educational Enrollments in States of India. Demography 2001;38(1):115-132. [PubMed: 11227840]

Gertler, Paul; Gruber, Jonathan. Insuring Consumption against Illness. American Economic Review 2002;92(1):50-70.

Goldstein, Markus; Udry, Christopher. Economic Growth Center Working Papers 929. Yale University; 2005. The Profits of Power: Land Rights and Agricultural Investment in Ghana.

Jacoby, Hanan G.; Skoufias, Emmanuel. Risk, Financial Markets, and Human Capital in a Developing Country. Review of Economic Studies 1997;64(3):311-335.

Jha, Raghavendra. Calories Deficiency in Rural India in the Last Three Quinquennial Rounds of the NSS. 2004. http://eprints.anu.edu.au/archive/00001701/ 
Meenakshi JV, Vishwanathan Brinda. Calorie Deprivation in Rural India, 1983-1999/2000. Economic and Political Weekly 2003 January 25;:369-375.

Morduch, Jonathan. Income Smoothing and Consumption Smoothing. Journal of Economic Perspectives 1995;9(3):103-114.

Morduch, Jonathan. Micro-Insurance: The Next Revolution?. In: Banerjee, Abhijit; Benabou, Roland; Mookherjee, Dilip, editors. What Have We Learned About Poverty?. Oxford University Press; 2006.

Munshi, K.; Rosenzweig, M. Working Paper 097. BREAD [Bureau for Research and Economic Analysis of Development]; 2005. Why is Social Mobility in India so Low? Social Insurance, Inequality, and Growth.

Prathman. Annual Status of Education Report, 2006. Mumbai: PRATHAM; 2006.

Ravallion, Martin. Pessimistic on Poverty? The Economist. 2004April 7, 2004

Rose, Elaina. Consumption Smoothing and Excess Female Mortality in Rural India. Review of Economics and Statistics 1999;81(1):41-49.

Rubalcava, L.; Teruel, G. CIDE \& UIA working paper. 2004. The Mexican Family Life Survey Project (MxFLS): Study Design and Baseline Results.

Rutherford, Stuart. The Poor and Their Money. New Dehli: Oxford University Press; 2000.

Sala-i-Martin, Xavier. More or Less Equal. The Economist. 2004March, 11, 2004

Shaban, Radwan. Testing between Competing Models of Sharecropping. Journal of Political Economy 1987;95(5):893-920.

De Soto, Hernando. The Mystery of Capital: Why Capitalism Triumphs in the West and Fails Everywhere Else. Basic Books; 2003.

Thomas D, Strauss J. Health and Wages: Evidence on Men and Women in Urban Brazil. Journal of Econometrics 1997;77(1):159-185. [PubMed: 12292719]

Thomas, Duncan, et al. Mimeo: UCLA; 2004. Causal Effect of Health on Labor Market Outcomes: Evidence from a Random Assignment Iron Supplementtion Intervention. http://www.ccpr.ucla.edu/ccprwpseries/ccpr_022_04

Townsend, Robert. Financial Systems in Northern Thai Villages. Quarterly Journal of Economics 1995;110(4):1011-1046.

Udry, Christopher. Credit Markets in Northern Nigeria: Credit as Insurance in a Rural Economy. World Bank Economic Review 1990;4(3):251-269.

Wagstaff, Adam. Child Health on One Dollar a Day. Social Science \& Medicine 2003;57(9):1529-1538. [PubMed: 12948564]

World Health Organization Expert Consultation. Appropriate Body-Mass Index for Asian Populations and Its Implications for Policy and Intervention Strategies. Lancet 2004;363(9403):157-163.

[PubMed: 14726171] 


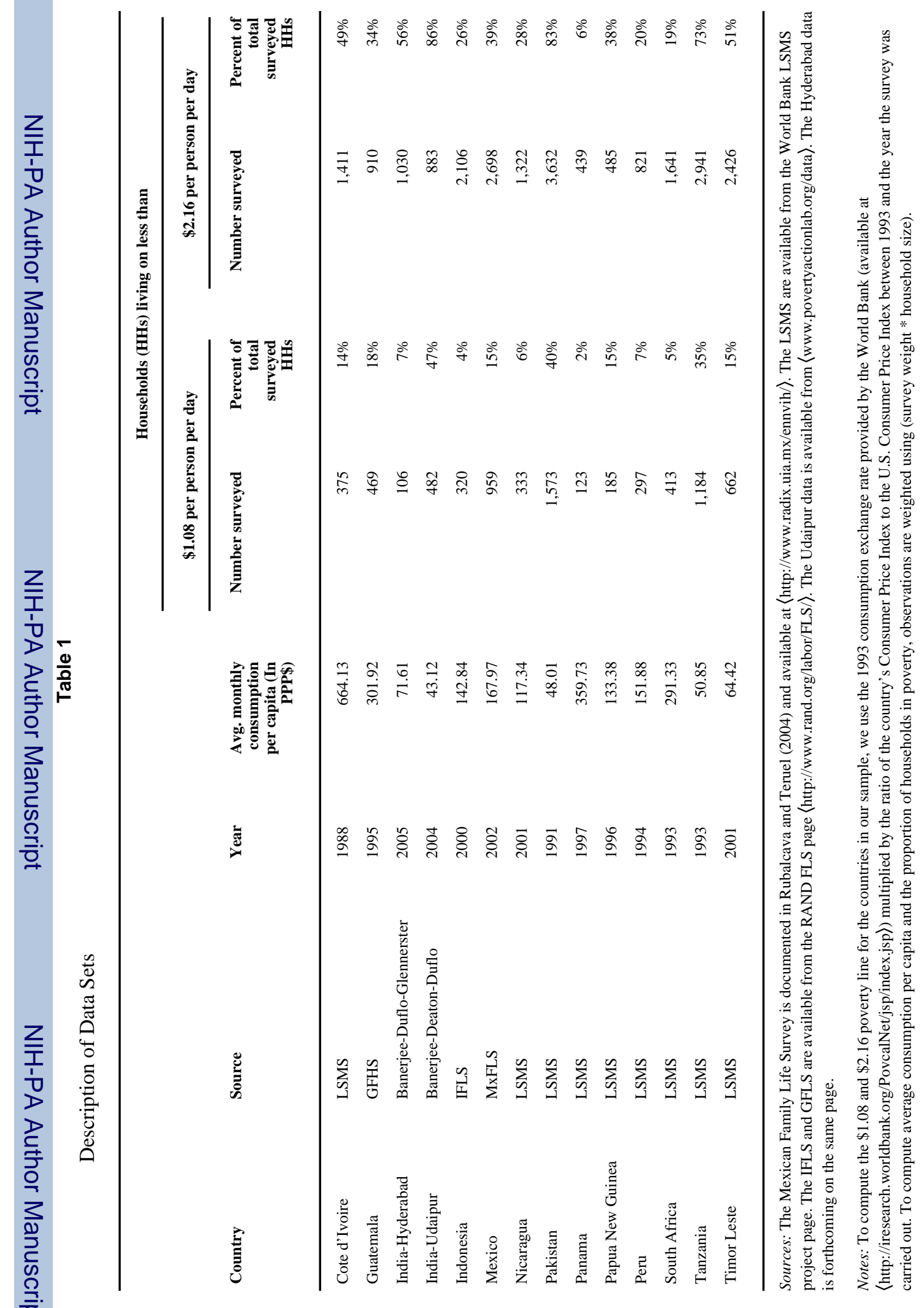

$J$ Econ Perspect. Author manuscript; available in PMC 2009 February 10. 